\title{
DESAIN PERENCANAAN STRATEGI PENGEMBANGAN POTENSI WISATA KULINER DAN BELANJA KOTA BANDUNG
}

\author{
Amelda Pramezwary ${ }^{1}$, Juliana ${ }^{2}$, Ira B. Hubner ${ }^{3}$ \\ ${ }^{1,2,3}$ Fakultas Pariwisata,Universitas Pelita Harapan \\ amelda.pramezwary@uph.edu, juliana.stpph@uph.edu, ira.hubner@uph.edu \\ (Corresponding author : Juliana.stpph@uph.edu)
}

\begin{abstract}
ABSTRAK
Kota Bandung merupakan kota Metropolitan terbesar di Jawa Barat dan juga merupakan ibu kota provinsi, serta pernah menjadi tempat terlaksananya Konferensi Asia Afrika 1955. Kota Bandung dengan segala potensi sumber daya yang dimilikinya dikenal akan wisata alam dan budayanya. Namun dengan perkembangan yang ada beberapa tahun terakhir ini, Bandung mulai dikenal juga melalui potensi wisata kuliner dan belanja yang dimilikinya. Bahkan Kementrian Pariwisata telah menetapkan Bandung sebagai salah satu destinasi unggulan wisata kuliner dan belanja di Indonesia. Namun demikian, masih ada beberapa masalah yang dihadapi seperti belum terintegrasinya kawasan-kawasan wisata belanja dan kuliner yang menyebabkan pengembangan belum optimal, kurangnya ketersediaan fasilitas transportasi, lahan parkir, dukungan promosi dan kerjasama antar pemangku kepentingan. Penelitian ini berupaya untuk mengidentifikasi potensi dan tantangan wisata kuliner dan wisata belanja dengan menggunakan metoda kualitatif deskriptif. Pengumpulan data akan dilakukan melalui focus group discussion terhadap stakeholder pariwisata di Kota Bandung. Hasil dari penelitian ini adalah penyusunan strategi pengembangan wisata kuliner dan belanja kota Bandung.
\end{abstract}

Kata Kunci : destinasi, perencanaan strategi, wisata kuliner dan belanja

\section{ABSTRACT}

Bandung is the largest Metropolitan city in West Java and is also the capital of the province, and was the venue for the 1955 Asian-African Conference. The city of Bandung with all its potential resources is known for its natural and cultural tourism. However, with the developments that have occurred in the last few years, Bandung has also begun to be recognized by its culinary and shopping potential. Even the Ministry of Tourism has designated Bandung as one of the leading destinations for culinary tourism and shopping in Indonesia. However, there are still a number of problems faced, such as not yet integrated shopping and culinary tourism areas which have resulted in not optimal development, lack of availability of transportation facilities, parking lots, promotional support and cooperation between stakeholders. This study seeks to identify the potential and challenges of culinary tourism and shopping tourism by using a qualitative descriptive method. Data collection will be carried out through focus group discussions on tourism stakeholders in the city of Bandung. The results of this study are the formulation of a strategy for the development of culinary tourism and shopping in the city of Bandung.

Keywords: culinary and shopping tourism, destination, strategic planning

ISSN: 2355-6587, e-ISSN: 2528-2220

http://ejournal.bsi.ac.id/ejurnal/index.php/jp 


\section{PENDAHULUAN}

Seiring dengan perubahan global, paradigma pariwisata Indonesia sudah menunjukkan perubahan yang signifikan. Pada masa lampau spektrum pembangunan pariwisata lebih diorientasikan hanya pada beberapa kawasan penting, di mana sebenarnya dilihat dari kecenderungan perubahan pasar global yang lebih mengutamakan sumber daya lokal sebagai destinasi Pariwisata.

Pariwisata merupakan sektor perekonomian global yang dianggap paling menjanjikan. Pariwisata berkembang pesat dan menjadi industri potensial yang dapat memberikan kontribusi besar bagi pergerakan ekonomi suatu negara.

Kota Bandung merupakan salah satu kota yang berada di Jawa Barat dan merupakan destinasi yang menjadi pilihan favorit di Provinsi Jawa Barat. Warga masyarakat kota Bandung memiliki kreatifitas tinggi baik di bidang seni, kerajinan, kuliner dan fashion sehingga kota Bandung sekarang dikenal sebagai kota wisata belanja dan kuliner. Pada awalnya Bandung sangat terkenal dengan wisata alam dan wisata budaya, namun sekarang kondisi tersebut mulai berubah, dan Bandung lebih dikenal sebagai kota wisata belanja dan wisata kuliner. Hal itu terjadi terutama di pusat kota (Bandung bagian utara) yang didominasi oleh aktivitas perdagangan dan jasa.

Kontribusi sektor kuliner dan belanja dalam investasi pariwisata adalah sebesar $60 \%$ berasal dari HORECA WOW yang merupakan pelaku usaha kuliner dan belanja.

Sebelum pandemi selama dari tahun 2013 sampai dengan 2017, ratarata peningkatan jumlah kunjungan wisatawan ke Kota Bandung mencapai $19,95 \%$. Sampai dengan tahun 2017, dikatakan Kepala Dinas Kebudayaan dan Pariwisata Kota Bandung, wisatawan masuk mencapai 7 juta orang.
Tabel 1. Jumlah Wisatawan Mancanegara dan Domestik di Kota Bandung

\begin{tabular}{llll}
\hline Tahun & \multicolumn{2}{c}{ Wisatawan } & Jumlah \\
\hline & Mancanegara & Domestik & \\
\hline $\mathbf{2 0 1 3}$ & 176.432 & 5.388 .292 & 5.564 .724 \\
\hline $\mathbf{2 0 1 4}$ & 180.143 & 5.627 .421 & 5.807 .564 \\
\hline $\mathbf{2 0 1 5}$ & 183.932 & 5.877 .162 & 6.061 .094 \\
\hline $\mathbf{2 0 1 6}$ & 173.036 & 4.827 .589 & 5.000 .625 \\
\hline
\end{tabular}

Sumber : Dinas Kebudayaan dan Pariwisata Kota Bandung (2018)

Dengan situasi pandemi sejak awal tahun 2020 yang menerpa hampir semua kota di dunia termasuk Indonesia, kunjungan wisatawan terkena dampak yang besar. Apalagi setelah Jawa Barat menyatakan siaga 1 dalam menangani Covid-19, jumlah wisatawan dalam dan luar negeri yang datang ke Kota Bandung disebut menurun. Sebagai Ibu Kota Jabar, Kota Bandung disebut sebagai salah satu kota terdampak pascapengumuman tersebut.

Studi menurut (Komaladewi, 2017), pertumbuhan ekonomi Indonesia yang stabil seiring dengan peningkatan hasil pembangunan infrastruktur, membawa perubahan dalam gaya hidup. Kebutuhan rekreasi berupa pariwisata didukung dengan ketersediaan dan kemudahan aksesibilitas menuju destinasi.

Meningkatnya jumlah wisatawan berdampak pada semakin banyaknya sarana penunjang dan tawaran aktivitas wisata yang dapat dilakukan oleh wisatawan yang tinggal di destinasi wisata. Beberapa kota di Indonesia sudah dikenal dengan wisata kulinernya, sehingga setiap akhir pekan atau harihari libur kota-kota tersebut banyak dikunjungi oleh wisatawan yang datang untuk mencicipi kuliner tersebut.

(Pestek, A., \& Cinjarevic, 2014) menyatakan bahwa industri kuliner adalah komponen utama dalam industri pariwisata, dan pengalaman kuliner memberikan pengalaman penting bagi wisatawan. Wisata kuliner dan belanja merupakan salah satu pengembangan wisata minat khusus yang mengutamakan berwisata untuk 
menikmati makanan dan minuman dengan tujuan bersenang-senang.

Wiskulja berkelanjutan
mempromosikan produk lokal untuk alasan lingkungan dan sosial budaya. Sistem wiskulja lokal mempromosikan keberlanjutan lingkungan, keadilan sosial, dan perdagangan yang adil. Menciptakan pasar untuk spesialisasi produk lokal, pusat gastronomi destinasi, kerajinan tangan, pusat cenderamata lokal. fesyen/busana/kain lokal, pertanian dan sistem kuliner, rute sawah pertanian atau eco-museum serta menciptakan berbagai pengembangan produk lokal di daerah.

Wiskulja berkelanjutan tidak mewakili atau bukan merupakan sebuah jenis atraksi baru pada sebuah destinasi wisata melainkan bertujuan meningkatkan pariwisata lokal dengan cara menawarkan produk lokal dan warisan gastronomi/kuliner daerah serta belanja yang perlu dijaga agar dapat dinikmati terus menerus turun temurun dari gererasi ke generasi.

Sebagai salah satu kota besar di Indonesia, kota Bandung merupakan daerah tujuan wisata yang cukup terkenal, terutama wisata belanja di mana salah satu produk wisatanya adalah gastronomi. Pertumbuhan ekonomi kreatif yang pesat, memicu pemerintah Kota Bandung untuk terus mengembangkan empat sektor utama industri kreatif yaitu food (kuliner), fesyen, film, festivities (festival dan event). Produk wisata kuliner dan belanja (wiskulja) Kota Bandung sangat banyak dan beragam. Daerah yang telah menetapkan destinasi prioritas untuk destinasi wisata kuliner dan belanja yaitu Braga, Pascal, China Town, Burangrang, Atraksi wisata yang dapat dikemas dengan produk wisata kuliner dan belanja diantaranya Braga Culinary night, Locafore, Keukeun Festival. Produk wisata kuliner dan belanja saat ini dikenal oleh wisatawan melalui peran media dan event pariwisata.

Berdasarkan latar belakang di atas, ditetapkan perumusan masalah dalam penelitian ini : Bagaimana potensi kuliner dan belanja kota Bandung dilihat dari indikator target wisatawan, produk wisata kuliner dan belanja, kesiapan destinasi, sumber daya pendukung ? Bagaimana perencanaan strategi dan pengembangan potensi wisata kuliner dan belanja kota Bandung?

Tujuan dari penelitian ini adalah : memberikan gambaran potensi kuliner dan belanja kota Bandung berdasar pada indikator target wisatawan, produk wisata kuliner dan belanja, kesiapan destinasi, sumber daya pendukung serta untuk mengidentifikasi perencanaan strategis dan pengembangan wisata kuliner dan belanja kota Bandung.

Manfaat dari penelitian ini tidak hanya bermanfaat bagi pelaku industri wisata kuliner dan belanja, tetapi juga akan bermanfaat bagi wisatawan untuk melihat apa yang menarik untuk dikunjungi, bagi pemasok atau investor untuk mengetahui peluang bisnis di bidang wisata kuliner dan belanja, bagi pemerintah untuk melanjutkan program kebijakan yang kondusif bagi pengembangan wisata jenis ini, termasuk dalam penyediaan infrastruktur dan sumber daya pendukung.

\section{KAJIAN LITERATUR}

Menurut (Walker, 2010) definisi dari pariwisata adalah suatu hal yang dinamis, berkembang, dan merupakan industri terbesar di dunia, atau termasuk dari kumpulan industri, dimana semua komponen yang saling terkait berada dibawah satu payung yaitu pariwisata, wisata, penginapan, konvensi, ekposisi, pertemuan, acara, restoran, manajemen acara; perakitan, tujuan destinasi, dan juga rekreasi.

Pariwisata juga merupakan industri multidimensi dan beragam yang menyentuh banyak kegiatan ekonomi berbeda yang terhubung sebagai suatu sistem. Model sistem pariwisata disarankan oleh (Leiper, 1990) Pariwisata melibatkan orang-orang yang melakukan perjalanan ke suatu tempat atau tempat di luar komunitas asal untuk tujuan apa pun kecuali perjalanan 
pulang pergi setiap hari ke dan dari tempat kerja. Pada dasarnya, turis adalah petualang. Dan industri perjalanan pasti akan jauh lebih kecil jika orang tidak tertarik untuk menghabiskan waktu luang dengan bersantai, jalan-jalan, dan berpartisipasi dalam resort favorit dan kegiatan liburan (Vogel, 2016).

(Goeldner, C. R. dan Ritchie, 2012) memperjelas bahwa pariwisata berkaitan dengan orang yang datang ke suatu tempat untuk melihat-lihat, mengunjungi teman dan keluarga, berlibur dan menikmati waktunya. Pada saat memanfaatkan waktu luangnya, dapat melakukan berbagai aktivitas seperti berolahraga, berjemur, tur, atau menikmati lingkungan. Bahkan dapat juga sampai ke aktivitas konvensi, bisnis, bahkan belajar atau penelitian di luar daerah asalnya. Pariwisata merupakan fenomena yang kompleks. Setiap model yang menggambarkan pariwisata harus mampu menangkap berbagai komponen dari sistem pariwisata sekaligus proses dan hasil yang diharapkan dari pariwisata. Komponen pariwisata meliputi (Goeldner, C. R. dan Ritchie, 2012): (1) Wisatawan yaitu orang yang melakukan perjalanan. Destinasi berupaya agar apa yang dialami wisatawan pada saat berkunjung ke wilayahnya adalah pengalaman yang berkualitas, (2) Lingkungan dan Sumber Daya Alam yang menjadi penentu karakteristik suatu destinasi, (3) Lingkungan Terbangun meliputi budaya sebagai karakteristik permanen, infrastruktur dan fasilitas yang dibangun untuk kebutuhan penduduk maupun wisatawan, (4) Sektor Operasional dari Industri Pariwisata yang bagi orang awam dianggap "pariwisata". Di dalamnya meliputi transportasi, akomodasi, tempat makan dan minum, daya tarik wisata, tempat rekreasi dan hiburan, biro perjalanan serta sistem pendukung lainnya. (5) Keramahtamahan sebagai kelengkapan dari industri pariwisata, (6) Integrasi / Kolaborasi Perencanaan dan Pengembangan berupa kolaborasi antara seluruh pemangku kegiatan, baik swasta maupun pemerintah dan organisasi lainnya. (7) Proses, Aktivitas dan Hasil Pariwisata untuk menentukan hasil dan menjamin keberhasilan pariwisata di destinasi, serta (8) Karir Pariwisata yaitu seluruh segmen, organisasi, baik pemerintahan maupun swasta, termasuk di industri, memerlukan orang yang berkompeten di bidangnya.

Menurut (Weaver dan Lawton, 2014) menetapkan beberapa aspek yang menjadi faktor penarik bagi sebuah destinasi yaitu kedekatan geografis dengan pasar, aksesibilitas dari pasar, ketersediaan fasilitas, ketersediaan daya tarik wisata, hubungan budaya dan spiritual, keterjangkauan biaya, kedamaian, stabilitas dan keamanan, citra destinasi yang dilihat pasar serta kebijakan yang mendukung pariwisata.

Destinasi dan bisnis pariwisata terus mencari cara untuk meningkatkan dan memposisikan penawaran mereka. Mereka bertujuan untuk mencapai posisi yang lebih baik dan mendapatkan keunggulan kompetitif. Setiap tujuan harus memberikan pengalaman berharga dan operator pariwisata harus mencurahkan sumber daya mereka untuk melayani tamu mereka melalui penawaran mereka (Sotiriades, 2012).

Wisata kuliner dan belanja merupakan salah satu daya tarik wisata di sebuah destinasi wisata, yang menyediakan pengalaman bagi wisatawan yang datang untuk merasakan cita rasa sekaligus budaya dari sebuah destinasi.

Wisata Kuliner adalah "Kegiatan wisata yang berhubungan dengan makanan dan minuman dalam rangka menambah pengetahuan dan pengalaman berwisata, mempererat/memperkuat hubungan sosial, dan mengekspresikan gaya hidup" (Kemenparekraf, 2011).

Menurut UNWTO, dalam Global Report Foods Tourism 2012, Wisata Kuliner adalah Pengalaman perjalanan ke daerah Gastronomi, untuk rekreasi atau hiburan; yang mencakup kunjungan ke produsen makanan primer dan sekunder, festival dan pameran, 
petani dan pasar, acara memasak dan demonstrasi, mencicipi produk makanan berkualitas, dan kegiatan pariwisata lainnya yang berhubungan dengan makanan. Wisata kuliner berkembang dengan sangat dramatis, dalam berbagai bentuk di segala tempat (Swarbrooke, 2002), seperti acara dan festival bertema makanan dan minuman, pasar makanan dan minuman, makanan tradisional, industri makanan atau minuman yang menawarkan tur ke lokasi pembuatan, produsen makanan minuman yang mengembangkan daya tarik untuk meningkatkan citra merek-nya, peluang bagi wisatawan untuk datang ke lokasi perkebunan, serta hotel / akomodasi yang menyediakan makanan dan minuman yang khas sekaligus kesempatan untuk mempelajari cara mengolah makanan minuman tersebut.

Beberapa destinasi pariwisata, membuat rute perjalanan yang menggabungkan berbagai daya tarik bertema kuliner. Dengan meningkatnya minat akan nutrisi, masakan, dan keahlian memasak secara mendunia, sepertinya semakin banyak destinasi yang mencoba menggunakan masakan dan tradisi kuliner mereka sebagai aset pariwisata untuk memperkaya dan membedakan penawaran bagi para wisatawan potensial. (Okumus, F., Kock, G., Scantlebury, 2013) Dalam konteks ini, destinasi wisata dunia mencari potensi kuliner untuk mengembangkan daya tarik wilayahnya.

Definisi wisata kuliner harus mempertimbangkan sudut pandang pengalaman pengunjung, karena seperti bentuk pariwisata lainnya, aktivitas pariwisata tergantung pada permintaan. Dapat dikatakan bahwa wisata kuliner merupakan gabungan dari suatu bentuk perilaku konsumen, dimana kuliner adalah cara untuk mengalami budaya dan cita rasa yang baru, Strategi yang digunakan destinasi untuk mengembangkan dan memasarkan daya tarik dan pencitraan kuliner. Oleh karena itu, ini adalah kegiatan pariwisata yang berkontribusi untuk memperkaya pengalaman liburan di destinasi wisata dan untuk mencapai tujuan ekonomi dan sinergi dalam pemanfaatan produk lokal, cara unik untuk membedakan penawaran tujuan melalui branding (Okumus, F., Kock, G., Scantlebury, 2013).

Dengan pertumbuhan yang cepat dari industri pariwisata global, belanja sebagai salah satu kegiatan favorit wisatawan telah menjadi kontributor ekonomi yang signifikan bagi industri pariwisata dan ritel. Pentingnya berbelanja dalam keseluruhan pengalaman wisatawan telah mulai menarik perhatian yang meningkat dari produsen produk terkait pariwisata, pemasar, pengecer, dan peneliti. Aktivitas belanja sering kali merupakan kategori pengeluaran paling signifikan untuk liburan dan perjalanan. (Meng, F. dan $\mathrm{Xu}, 2012$ ).

Atribut belanja pariwisata. Untuk meningkatkan daya tarik area perbelanjaan bagi wisatawan, (Jansen, 1991) menyarankan kriteria spesifik berikut: pengelompokan dari berbagai toko, katering, rekreasi, dan kegiatan dan atraksi lainnya, Aksesibilitas dan parkir yang baik, Prioritas pedestrian atas kendaraan, Citra positif, Desain yang menarik (estetika), Ketersediaan selama waktu senggang (misalnya hari Minggu), Keramahtamahan (orientasi pengunjung, informasi yang memadai, identifikasi simbolisme), Nilai afektif social , Keindahan atau animasi, dengan unsur-unsur kejutan.

Perencanaan strategis dan manajemen diterapkan di tempat tujuan. Di mana inovasi dalam pariwisata berlangsung - produk baru harus dikembangkan dan "pengalaman" disampaikan kepada wisatawan (Leiper, 1990).

Organisasi Katalisator, Perencanaan, Pengembangan dan Promosi merupakan komponen yang tidak langsung terlihat, namun merupakan komponen penting dari sebuah destinasi wisata. Kolaborasi antara seluruh pemangku kegiatan, baik swasta maupun pemerintah dan organisasi lainnya penting di dalam menentukan perencanaan strategis. 
Untuk menjamin keberhasilan pariwisata di destinasi, organisasi yang bertanggungjawab harus menentukan filosofi pariwisata dari wilayahnya, untuk menentukan langkah-langkah pengembangan dan manajemen yang harus dilakukan. (Goeldner, C. R. dan Ritchie, 2012). Proses perencanaan strategis melibatkan persiapan cara terbaik untuk menanggapi keadaan lingkungan organisasi (Okumus, F., Kock, G., Scantlebury, 2013) Menjadi strategis berarti memperjelas tujuan organisasi, menyadari sumber daya organisasi dan menggabungkan keduanya sehingga menjadi secara sadar merespons terhadap lingkungan yang dinamis.

Berkenaan dengan perencanaan strategis, beberapa aspek penting harus ditunjukkan: pendekatan yang sangat efisien untuk perencanaan strategis adalah dengan mengadopsi pendekatan sistem yang dimulai dengan tujuan akhir yang ingin dicapai, kegiatan manajerial difokuskan pada hasil, pendorong hasil dan peningkatan kinerja, fokusnya adalah pada kebutuhan pelanggan dan pemangku kepentingan

\section{METODE PENELITIAN}

Penelitian ini menggunakan metode penelitian kualitatif deskriptif. Menurut (Creswell, 2013) mengemukakan metode penelitian kualitatif merupakan metode penelitian yang digunakan untuk meneliti pada kondisi objek yang alamiah. Pengumpulan data dilakukan dalam bentuk diskusi kelompok fokus (Focus group discussion), dengan memberikan cek list pertanyaan dan jawaban pertanyaan terbuka.

Penelitian ini berupaya untuk mengidentifikasi potensi wisata kuliner dan wisata belanja dan selanjutnya akan dilakukan penyusunan strategi pengembangan wisata kuliner dan belanja khas kota Bandung. Penelitian akan dilakukan di kota Bandung dengan subjek penelitian pemangku kepentingan sebagai responden meliputi para wisatawan, pemerintah, pelaku bisnis kuliner dan belanja. Indikator yang akan dikaji dalam penelitian ini mencakup di dalamnya potensi wisatawan, produk wisata kuliner dan belanja, destinasi dan sumber daya pendukung.

\section{PEMBAHASAN}

Pembahasan yang dilakukan berasal dari informasi yang didapatkan pada saat Focus Group Discussion (FGD) bersama pemangku kegiatan. Kota Bandung dikenal sebagai salah satu destinasi wisata unggulan di tingkat provinsi (Jawa Barat), nasional, bahkan internasional. Perkembangan pariwisata Kota Bandung ditopang oleh ketersediaan dan variasi produk wisata perkotaan dalam bentuk berbagai fitur kota, baik elemen primer maupun sekunder, termasuk pengetahuan, sejarah, budaya, heritage, kuliner, belanja, dan lain sebagainya. Sejalan dengan fungsi Bandung sebagai ibukota provinsi Jawa Barat dan kota jasa, produk pariwisata MICE (Meeting, Incentive, Conference, Exhibition), serta wisata berbasis pendidikan (knowledgebased tourism) juga menjadi unggulan utama.

Kota Bandung berhasil meraih Gold Medal sebagai Kota Terbaik Kategori Pariwisata dalam Indonesia's Attractiveness Award 2018. Penilaian penghargaan ini dilakukan melalui pengukuran Indonesia Attractiveness Index (IAI). Award ini merupakan penghargaan yang diselenggarakan oleh Frontier Consulting Group dan Tempo Media Group yang bertujuan melakukan pengukuran dan observasi terhadap daya tarik setiap daerah di Indonesia. Penghargaan ini dilatarbelakangi oleh pertumbuhan ekonomi dan daya saing setiap daerah di Indonesa untuk mendapatkan investasi yang berimplikasi terhadap terciptanya lapangan pekerjaan, peningkatan pendapatan daerah, dan mendorong tingkat konsumsi masyarakat. Keunikan budaya, keragaman kuliner, produk kreatif yang mengagumkan, penataan lokasi belanja yang menarik, suasana kota yang inspiratif, serta lansekap alam 
yang mempesona menjadikan Kota Bandung sebagai destinasi wisata primadona dan berhasil meraih indeks pariwisata tertinggi di Indonesia $(95,30)$, mengungguli Denpasar (87,65), dan Yogyakarta $(86,68)$.

Dari data yang dihimpun Disbudpar Kota Bandung berhasil mengidentifikasi potensi seni budaya yang luarbiasa, seperti dapat dilihat pada tabel di bawah ini.

Tabel 2. Potensi Seni dan Budaya Kota Bandung

\begin{tabular}{lrl}
\hline Jenis & Jumlah & Keterangan \\
\hline $\begin{array}{l}\text { Lingkung } \\
\text { Seni }\end{array}$ & 625 & Seni Pertunjukan \\
\hline $\begin{array}{l}\text { Bangunan } \\
\text { Cagar } \\
\text { Budaya }\end{array}$ & 1.701 & Gaya Art-deco \\
\hline $\begin{array}{l}\text { Komunitas } \\
\text { Ekonomi }\end{array}$ & & \\
Kreatif & & $\begin{array}{l}\text { Fashion, music, } \\
\text { film dan kuliner }\end{array}$ \\
\hline $\begin{array}{l}\text { Objek } \\
\text { Budaya }\end{array}$ & 2.635 & $\begin{array}{l}\text { Modal atraksi } \\
\text { wisata }\end{array}$ \\
\hline \begin{tabular}{l} 
Sumber : Dinas Kebudayaan dan \\
Pariwisata Kota Bandung (2018) \\
\multicolumn{2}{c}{ Seperti yang disebutkan }
\end{tabular}
\end{tabular}

(Goeldner, C. R. dan Ritchie, 2012), wisatawan adalah orang yang melakukan perjalanan. Destinasi berupaya agar apa yang dialami wisatawan pada saat berkunjung ke wilayahnya adalah pengalaman yang berkualitas. Penting bagi pembuat keputusan untuk mengetahui apa yang menjadi motivasi wisatawan, apa yang mempengaruhi pengambilan keputusan, moda yang digunakan dan pilihan utama dalam memenuhi kebutuhan perjalanannya. Data tentang target wisatawan adalah untuk mengetahui apakah daerah sudah memiliki studi tentang target wisatawan, dan tentang profil wisatawan baik domestic maupun mancanegara.

Dari Focus Group Discussion (FGD), diketahui bahwa sebelum terjadinya pandemi covid 19, Kota Bandung telah melakukan studi tentang target wisatawan dan profil wisatawan. Dinas Kebudayaan dan Pariwisata Kota Bandung menargetkan jumlah kunjungan wisatawan di tahun 2017 sebanyak 6,9 juta dan hasilnya tercapai melebihi target (over target) yaitu sebesar 7 juta wisatawan. Di tahun 2018, Kota Bandung menyelenggarakan Asian Africa Carnival dihadiri oleh 17 Negara yang mewakili 4 benua, yaitu Asia, Afrika, Eropa, Australia.

Dari diskusi FGD didapatkan data bahwa segmentasi wisatawan yang datang berkunjung ke Kota Bandung mayoritas menyukai wisata yang bersifat historikal dan kuliner serta belanja. Hal ini didukung oleh banyaknya koleksi bangunan bersejarah bergaya Art Deco yang masih terawat baik di Bandung, dan menempati peringkat 9 di dunia.

Menurut UNWTO, wisata Kuliner adalah pengalaman perjalanan ke daerah Gastronomi, untuk rekreasi atau hiburan; yang mencakup kunjungan ke produsen makanan primer \& sekunder, festival dan pameran, petani dan pasar, acara memasak dan demonstrasi, mencicipi produk makanan berkualitas, dan kegiatan pariwisata lainnya yang berhubungan dengan makanan.

Kota Bandung memiliki potensi kuliner unggulan yang luarbiasa. Di antaranya Batagor (dengan saus kacang yang khas dan rasa yang lezat), Gepuk (dimasak dengan proses yang unik menggunakan bumbu-bumbu tradisional) yang sangat memungkinkan untuk dijadikan ikon kuliner. Beberapa di antaranya telah menjadi viral di media sosial, seperti Facebook dan Instagram.

Untuk meningkatkan daya tarik area perbelanjaan bagi wisatawan, (Jansen, 1991) menyarankan kriteria spesifik berikut: (1) Pengelompokan dari berbagai toko, katering, rekreasi, dan kegiatan dan atraksi lainnya, (2) Aksesibilitas dan parkir yang baik, (3) Prioritas pedestrian atas kendaraan, (4) Citra positif, (5) Desain yang menarik (estetika), (6) Ketersediaan selama waktu senggang (misalnya hari Minggu), (7) Keramahtamahan (orientasi pengunjung, informasi yang memadai, identifikasi simbolisme), (8) Nilai afektif sosial, (9) Keindahan atau animasi, dengan unsur-unsur kejutan. 
Dari hasil FGD juga diketahui bahwa dalam pengembangannya, jenisjenis kuliner tersebut dikembangkan oleh masyarakat. Beberapa kuliner beraglomerasi (berkelompok), sehingga menjadi satu Kawasan tanpa intervensi dari pemerintah seperti Cikapundung, Gardujati, dan Cibadok. Pengelompokan wisata kuliner dan belanja ini menjadi sangat penting untuk meningkatkan daya tarik dan citra yang lebih besar dibandingkan berada di lokasi yang terpisah-pisah. Namun ada juga Kawasan kuliner dan belanja yang sengaja didesain khusus oleh pihak swasta seperti Rumah Mode, China Town, atau juga yang digagas Pemerintah Daerah seperti kawasan Riau dan Burangrang.

Produk-produk merchandise yang diunggulkan di antaranya produk fesyen/distro. Pertumbuhan subsektor fesyen di Kota Bandung mulai ramai sejak banyaknya distro di awal tahun tahun 2000-an menjadi faktor utama perkembangan industri fesyen Kota Bandung terutama dalam hal Fesyen Muslim atau Modest Fashion. Beragam produk fesyen yang menjajal peruntungan ekspor antara lain tas buatan tangan dan pakaian dengan variasi model yang tren saat ini. Tidak hanya itu, produk fesyen juga memiliki ciri keunikan yang berbeda dengan daerah lain. Banyaknya desainer dari Bandung membuat kota ini memiliki peran memajukan Indonesia di bidang fesyen. Menurut Penilaian Mandiri Kota/Kabupaten Kreatif Indonesia (PMK3I) Deputi Infrastruktur Badan Ekonomi Kreatif Indonesia, omzet fesyen Kota Bandung mencapai 3-5 trilyun rupiah setiap tahunnya.

Beberapa pasar bahkan banyak dikunjungi oleh wisatawan mancanegara dari Malaysia. Pasar Malaysia merupakan pasar yang sangat potensial untuk membeli produk fesyen, khususnya produk busana muslim dan perlengkapannya. Beberapa produk fesyen sudah menjadi produk yang diekspor ke negara-negara lain.
Tabel 3. Potensi Wisata Kuliner dan Belanja Kota Bandung

\begin{tabular}{|c|c|}
\hline Wisata Kuliner & Wisata Belanja \\
\hline $\begin{array}{l}\text { 1. Makanan dan } \\
\text { Minuman Asli } \\
\text { Lokal (Batagor, } \\
\text { Gepuk, Bandrek, } \\
\text { Cilok, Cireng, } \\
\text { Bandung Pletok) }\end{array}$ & $\begin{array}{l}\text { 1. Seni kerajinan } \\
\text { lokal/asli daerah } \\
\text { (Leather goods; } \\
\text { sepatu \& tas } \\
\text { Cibaduyut, } \\
\text { Wayang Golek, } \\
\text { Angklung) }\end{array}$ \\
\hline
\end{tabular}

2. Pasar tradisional 2. Wisata Oleh(Cihapit, oleh (Kartika Kosambi, Pasar sari, Primarasa, Baru, dll) Amanda Brownies)

3. Urban
Kampoeng
4. Bandung
Heritage Food
Tour/gastronomy
Tour

5. Farming (Lahan perkebunan, pertanian, peternakan) yang berada disekitar Bandung Barat dan Selatan, potensi kerjasama pengembangan lintas kabupaten

6. Belajar memasak makanan lokal

7. Festival, kompetisi kuliner lokal

3. Fesyen (Jeans, Batik Patra Komala Bandung, Busana Muslim, Pabrik Kaos/tekstil, Factory Outlet)

4. Belajar membuat kerajinan asli

5. Arsitektur peninggalan local (menciptakan suasana / ambience yang berbeda dari kota lain)

6. Festival Belanja

Sumber : Hasil Olahan Data (2020)

Kota Bandung yang berbatasan langsung dengan Kota Lembang juga memberikan peluang untuk mengkaitkan wisata kuliner dan belanja dengan destinasi lain, perkebunan atau peternakan yang banyak tersebar di Kawasan Lembang. Pembuatan tahu, produk-produk susu sapi, strawberi dapat dinikmati langsung di Kawasan ini.

Produk wisata kuliner dan belanja saat ini dikenal oleh wisatawan melalui peran media sosial, seperti Instagram dan Facebook, serta beberapa event pariwisata di Kota Bandung. Wisatawan yang mengunjungi Kota Bandung, tidak 
akan melupakan untuk berfoto di lokasi wisata kuliner maupun belanja, dan langsung mengunggahnya ke media social. Wisata kuliner dan belanja di Kota Bandung sudah dikembangkan dengan mengadakan event-event yang menarik terutama menyasar segmen pasar milenial, di antaranya Bandung Great Sale, Braga Culinary Night, Keukeun Fest.

Sebenarnya Pemda memiliki web yang memanfaatkan teknologi informasi yang memuat informasi produk-produk wisata khususnya kuliner dan belanja yaitu di antaranya: https://bandungtourism.com sebagai pusat informasi on-line seputar pariwisata di Kota Bandung dan https://littlebandung.co.id sebagai website yang difokuskan untuk pemasaran luar negeri. Pemda telah juga mempersiapkan pusat informasi kuliner dan belanja berbasis digital. Destinasi pariwisata yang ada diintegrasikan dengan tema wisata kuliner dan belanja, misalnya Pascal, Cihampelas, Rumah Mode. Ada 6 tema yang dihasilkan dengan mengintegrasikan destinasi yang ada tersebut, yaitu kuliner, belanja, kuliner dan belanja, heritage, alam dan budaya, wisata buatan manusia.

Pembahasan berikut adalah melihat beberapa permasalahan yang masih dihadapi dalam pengembangan wisata kuliner dan belanja di Kota Bandung. Pertama adalah peran komunitas. Kota Bandung belum banyak memiliki komunitas khusus tentang wiskulja, sehingga belum dapat melakukan pengembangan destinasi yang melibatkan kerjasama dengan komunitas secara optimal. Komunitas sangat berperan dalam penyeleggaraan kegiatan wiskulja ini. Kegiatan yang dapat dilakukan komunitas sangat beragam macamnya mulai temu rutin, workshop untuk berbagi informasi, membicarakan pengembangan potensipotensi yang ada, bersinergi menggalang dana atau akses terhadap pendanaan hingga penyelenggaraan event atau pameran yang berskala Nasional dan Internasional.

Masalah kedua adalah koordinasi lintas sektoral. Kota Bandung memiliki berbagai kegiatan di destinasi yang memerlukan perencanaan fasilitas (akses, akomodasi, amenitas, dan atraksi) untuk kemudahan, kenyamanan dan daya tarik bagi wisatawan. Namun, seringkali implementasi penyediaan fasilitas masih menemui masalah dikarenakan beberapa hal termasuk pengaruh dari iklim politik. Ketersediaan aksesibilitas sebenarnya sudah direncanakan, namun masih ada beberapa kendala. Prioritas pembangunan infrastruktur yang dilakukan Pemda mengacu pada permintaan masyarakat melalui Musrenbang, Anggota Dewan, dan kebijakan pemerintah. Pembangunan infrastruktur pariwisata memperoleh perhatian yang sama dengan sektor lainnya. Dengan kendala ini, infrastruktur menjadi tertunda ketersediaannya, beberapa ruas jalan mengalami kemacetan yang parah terutama pada waktu akhir pekan atau hari-hari libur. Trotoar jalan dan lahan parkir khususnya di Kawasan kuliner dan belanja tidak tersedia atau tidak mencukupi.

Masalah ketiga yang perlu dikaji juga adalah sumber daya pendukung wisata, dengan melihat upaya sertifikasi dan ketersediaan bahan baku. Saat ini pelaku usaha kuliner dan belanja belum memiliki sertifikasi internasional, bahkan belum semua pelaku usaha memiliki sertifikasi nasional. Hal ini sesuai dengan yang ditetapkan dalam UU No. 1 tahun 2016 tentang Penyelenggaraan Sertifikasi Usaha Pariwisata. Tanpa sertifikasi akan membatasi gerak usaha dari pelaku usaha tersebut, misalnya untuk upaya ekspor. Sudah ada upaya Pemda untuk meningkatkan sertifikasi usaha kuliner dan belanja, namun belum maksimal dan belum tersosialisasikan dengan baik. Upaya Pemda dalam meningkatkan kapasitas pelaku usaha kulja dilakukan 
melalui program penyuluhan, namun belum merata.

Inkubator bisnis berbasis pariwisata kulja sudah dilakukan, namun belum menyeluruh dan belum maksimal. Diperlukan fasilitas kemudahan untuk mengembangkan jejaring antar pengusaha pariwisata. Tidak banyak pelaku usaha pariwisata (khususnya kulja) yang memanfaatkan sumberdaya lokal untuk usahanya. Ini karena ketersediaan bahan baku lokal untuk mendukung usaha tersebut tidak konsisten, baik kualitas maupun kuantitas.

Proses perencanaan strategis melibatkan persiapan cara terbaik untuk menanggapi keadaan lingkungan organisasi (Okumus, F., Kock, G., Scantlebury, 2013). Menjadi strategis berarti memperjelas tujuan organisasi, menyadari sumber daya organisasi dan menggabungkan keduanya sehingga menjadi secara sadar merespons terhadap lingkungan yang dinamis. Dengan mengkaji potensi dan masalah yang ada dari wisata kuliner dan belanja di Kota Bandung, berikut adalah rencana strategi pengembangan :

Strategi pengembangan wisata kuliner dan belanja (wiskulja) di kota Bandung akan difokuskan pada strategi pengembangan wiskulja berkelanjutan (Sustainable Gastronomy/Culinary and shopping destination). Hal ini sebenarnya sudah sejalan dengan pelaksanaan Bandung Tourism brand activation sejak tahun 2016 oleh Dinas Kebudayaan dan Pariwisata Kota Bandung dimana Sustainable Urban Tourism merupakan konsep pengembangan yang diangkat oleh Disparbud Kota Bandung. Wiskulja berkelanjutan diharapkan dapat menjadi strategi pengembangan yang sesuai dengan konsep pengembangan pariwisata kota bandung, dimana potensi kuliner otentik khas serta belanja khas kota Bandung dapat diangkat menjadi program pengembangan yang berdampak positif memberikan manfaat ekonomi bagi masyarakat lokal dan pelaku dengan tetap menjaga, memperhatikan unsur kelestarian budaya dan lingkungan.

Hal-hal yang dapat dilakukan
untuk mengembangkan potensi Destinasi Wiskulja Berkelanjutan adalah (1) Peka terhadap kondisi lokal dan otentik - gunakan bahan pembuatan produk makanan yang diproduksi lokal, pertanian dan produk organik, budaya kehidupan tradisional, produksi makanan tradisional, kerajinan tradisional (produk fesyen, kain, batik, seni dan kerajinan tangan khas Bandung), (2) Masakan yang menarik, yang tidak biasa, belum dikenal oleh seluruh masyarakat dapat dianggap sebagai sumber daya destinasi dan perlu dianggap sebagai produk yang dapat menjadi branding dari destinasi (dalam hal ini kota Bandung terkenal dengan berbagai produk olahan singkong; colenak, kripik, peuyeum, Batagor, Siomay, Cireng, Cilok, Seblak, Gepuk, Mie Kocok, Cuanki). Pemerintah Daerah berencana mengembangkan sentra kuliner dan belanja dengan tema khusus, di antaranya Cibaduyut, Cihampelas, Cigading. (3) Rute gastronomi dan belanja lokal dapat mempromosikan destinasi dan dapat berkontribusi pada proyek pengembangan wiskulja yang berkelanjutan. (Saat ini belum terdapat rute kuliner dan belanja Bandung Ifood \& shopping tour, food track) (4) Restoran khas, pusat perbelanjaan dengan gaya arsitektur alami, dan tokotoko khas dan bersejarah dapat dikembangkan untuk membantu promosi wiskulja kekhasan destinasi.

Dalam mengimplementasikan wiskulja berkelanjutan dibutuhkan berbagai inisiasi dan dukungan, diantaranya (1) perencanaan sarana, prasarana dan sistem tata kelola pariwisata berkelanjutan di destinasi untuk mendukung pengembangan Wiskulja serta kerjasama dan komitment lintas sektoral), (2) desain arsitektur, lansekap yang mengusung tema lokal (Kearifan Lokal), (3) kreatifitas dan inovasi dalam membuat/ mengemas produk wisata kuliner dan belanja 
berkelanjutan di destinasi, (4) pemasaran dan promosi yang bertanggungjawab menjadikan produk kuliner dan belanja tersebut menjadi terkenal yaitu dengan cara branding, advertising, selling dan strategi pemasaran, misalnya melalui media sosial, sponsor, penjualan offline dan online, (5) kurasi interpretasi dengan berbagai cara termasuk story telling, mapping potensi wiskulja, (6) kepedulian, tanggungjawab dan kebijakan tentang Daya Dukung atau Carrying Capacity dan Visitors Management khususnya dalam situasi pandemic covid 19 seperti ini dimana pengunjung harus jaga jarak dan menjalankan protocol Kesehatan dan kebersihan, (7) kepedulian, tanggung jawab dan kebijakan tentang Waste management, Hygiene Sanitation, (8). ketersediaan transportasi dalam kota yang ramah lingkungan untuk mengatasi kemacetan di Kota Bandung khususnya dan memberikan kenyamanan bagi pengunjung, (9) packaging kuliner dan belanja yang ramah lingkungan (No Plastic, No Styro Foam).

\section{PENUTUP}

Simpulan dari penelitian ini adalah Kota Bandung memiliki potensi wisata kuliner dan belanja yang sudah berkembang dan banyak dikunjungi oleh wisatawan baik lokal maupun mancanegara. Daerah yang telah menetapkan destinasi prioritas untuk kuliner dan belanja, yaitu Braga, Pascal, China Town, Burangrang. Pemerintah Daerah berencana mengembangkan sentra kuliner dan belanja dengan tema khusus, di antaranya Cibaduyut, Cihampelas, Cigading. Dalam pengembangannya akan diarahkan menjadi Wisata Kuliner dan Belanja Berkelanjutan yang akan lebih memperhatikan kekayaan potensi lokal, baik sumber daya bahan baku lokal (seperti sayur, buah, produk hewani untuk kuliner dan bahan fesyen, kulit sapi, atau berbagai bahan untuk kerajinan) maupun pelaksanaan oleh penduduk lokal sebagai pelaku usaha. Hal ini perlu diupayakan agar masyarakat lokal yang pertama-tama akan mendapatkan manfaat dari adanya kegiatan wisata kuliner dan belanja ini.

Saran dan rencana keberlanjutan penelitian adalah studi pasar wisatawan kuliner dan belanja yang lebih terarah dan detail untuk mendapatkan informasi minat, motivasi dan prevalensi sehingga dapat diketahui pengembangan produk wisata kuliner dan belanja yang sesuai dengan kebutuhan pasar.

\section{REFERENSI}

Creswell, J. W. (2013). Research Design: Qualitative, Quantitative, and Mixed Methods Approaches (4th ed.). In Research design Qualitative quantitative and mixed methods approaches. https://doi.org/10.1007/s13398014-0173-7.2

Goeldner, C. R. dan Ritchie, J. R. (2012). Tourism - principles, practices, philosophies.

Jansen, V. (1991). Leisure shopping: a major concept for the tourism industry? Journal of Tourism Management.Diakses Dari Emerald Publishing Limited., 12(1).

Komaladewi, R. (2017). The Representation of Culinary Experience as the Future of Indonesian Tourism Cases in Bandung City, West Java. International Journal of Business and Economic Affairs, 2(5). https://doi.org/10.24088/ijbea2017-25001

Leiper, N. (1990). Tourism Systems. Department of Management Systems Occasional Paper 2.

Meng, F. dan Xu, Y. (2012). Tourism shopping behaviour: planned, impulsive, or experiential? International Journal of Culture, Tourism and Hospitality Research, 6(3).

Okumus, F., Kock, G., Scantlebury, M. (2013). Using local cuisines when 
promoting small Caribbean island destinations. Journal of Travel and Tourism Marketing.Diakses Dari Emerald Publishing Limited, 30(4).

Pestek, A., \& Cinjarevic, M. (2014). Tourist perceived image of local cuisine: The case of Bosnian food culture. British Food Journal, 116(11), 1821-1838.

Sotiriades, M. (2012). Tourism destination marketing: approaches improving effectiveness and eficiency. Journal of Tourism and Hospitality Technology, 3(2).

Swarbrooke, J. (2002). The development and management of visitor attractions, 2 nd ed.

Vogel, H. L. (2016). Tourism. (tidak lengkap)

Walker, J. R. (2010). Tourism : concepts and practices. Prentice Hall; Pearson Education [distributor].

Weaver dan Lawton. (2014). Tourism Management, 5th ed.

\section{BIODATA PENULIS}

Amelda Pramezwary, merupakan dosen dan Ketua Program Studi Pengelolaan Perhotelan Fakultas Pariwisata Universitas Pelita Harapan

Juliana, merupakan dosen Fakultas Pariwisata Universitas Pelita Harapan

Ira B Hubner. merupakan dosen Fakultas Pariwisata Universitas Pelita Harapan 